УДК 62-5

I. А. Фольборт, I.P. Пархомей

\title{
АЛГОРИТМІЗАЦІЯ ПЛАНУВАННЯ ЕКТРОМАГНIТНОЇ СУМІСНОСТІ РАДІОЕЛЕКТРОННИХ ЗАСОБІВ
}

Анотація: У роботі проведено аналіз причин виникнення взаємних завад при роботі радіоелектронних засобів в ускладненій радіоелектронній обстановці, розглянуто сучасний науково-методичний апарат радіомоніторингу з визначенням в ньому електромагнітної обстановки для вирішення задач частотного планування радіоелектронні засоби(РЕЗ) рухомої служби.

Ключові слова: джерело радіовипромінення, електромагнітна обстановка, електромагнітна сумісність, пункт технічного радіоконтролю, радіовипромінюючий пристрій, радіорегламент, радіотехнології, радіочастотний ресурс.

\section{Вступ}

Алгоритм припускає проведення аналізу ЕКТРОМАГНІТНОЇ СУМІСНОСTI (ЕМC) РЕЗ у районі планування, а у випадку використання загальної платформи для розміщення РЕ3 - ЕМС локального групування РЕ3 (об'єктова ЕМС).

Об’єкт дослідження - процес визначення електромагнітної обстановки для вирішення задач частотного планування радіоелектронних засобів рухомої служби.

Предмет дослідження - дослідження та розрахунок ЕMC PEЗ в районі планування.

Мета роботи - дослідження ефективності використання та визначення напрямків удосконалення розрахунку ЕМС РЕЗ в районі планування.

У першому випадку враховуються завади наступних типів [2, 3, 4]:

- по основному каналу;

- по першому сусідньому каналу;

- завади інтермодуляції 3-го порядку.

В другому випадку, крім перерахованих вище, враховуються завади наступних видів [3, 4]:

- по сусідніх каналах;

- інтермодуляція вище 3-го порядку (до 13-го порядку включно);

- блокування;

- по дзеркальному каналу;

- по першій ПЧ;

- на гармоніках.

(C) I. А. Фольборт, I.P.Пархомей 
При проведенні аналізу, вищезазначеної методики був встановлений показник ефективності цієї методики, при менших витратах на виміри електромагнітної обстановки, та рекомендовано для широкого використання цієї методики, при контролю та управління радіочастотним ресурсом і забезпечення електромагнітної сумісності радіоелектронних засобів.

\section{Основна частина}

Інтенсивний розвиток сфери телекомунікацій безпосередньо пов'язаний 3 упровадженням у практику нових радіотехнологій і систем зв'язку, появою нових послуг i видів зв'язку. В цих умовах забезпечення потреб у радіочастотному ресурсі усіх категорій користувачів здійснюється за рахунок перерозподілу вже освоєних і подальшого освоєння нових діапазоні в частот.

Перерозподіл частот, у свою чергу, призводить до збільшення навантаження на вже освоєні діапазони радіочастот, що зумовлено зростанням кількості діючих PE3, і до ускладнення електромагнітної обстановки. Освоєння ж нових діапазонів частот диктує необхідність виділення смуг радіочастот для нових радіо технологій, систем і стандартів зв'язку. В цих умовах управління РАДІОЧАСТОТНИЙ РЕСУРС (РЧР) і забезпечення електромагнітної сумісності (ЕМС) PE3 та випромінювальних пристроїв (ВП) мають важливе практичне значення.

Нині у світі зареєстровано понад 127 тисяч передавачів аналогового й більше 2200 передавачів цифрового телебачення, а також більше 66 тисяч передавачів аналогового звукового мовлення, кількість абонентів мереж стільникового зв'язку другого покоління (2G) перевищує 2,5 млрд., кількість абонентів, які працюють у більше ніж 250 мережах зв'язку третього покоління (3G) (CDMA2000 і W-CDMA/UMTS), перевищує 250 млн.

Зрозуміло, що збільшення кількості РЕЗ призводить до перевантаження РЧР і ще більше ускладнює електромагнітну обстановку та ЕМС між РЕЗ і ВП.

Зараз переважна більшість завдань радіомоніторингу вирішується за допомогою автоматизованих методів із застосуванням сучасного обладнання. Але рівень розвитку радіомоніторингу дещо відстає від рівня розвитку телекомунікацій. Донині технічні можливості обладнання радіомоніторингу стосовно діапазону робочих частот обмежувалися в нижній частині РЧР частотою 30 МГц, а в його верхній частині - частотою 3 ГГц. Головним чином це зумовлено тим, що з усіх РЕЗ у смузі частот до 3 ГГц їх зосереджено більше ніж 90 \%.

Разом 3 тим, в останні роки розробники та виробники засобів телекомунікацій приділяють значну увагу вищим діапазонам радіочастот, які вважаються найперспективнішими для практичного освоєння. На цей час в Україні діапазон радіочастот 3,5 ГГц інтенсивно освоюється радіотехнологій 
WiMAX, діапазони радіочастот 6/4 ГГц, 8/7 ГГц, 14/11 ГГц і 30/20 ГГц насичуються супутниковими системами зв'язку.

Складність вирішення завдань радіомоніторингу в діапазонах частот понад 3 ГГц зумовлена:

- труднощами виявлення, визначення місцезнаходження ДЖЕРЕЛА РАДІОВИПРОМІНЕННЯ (ДРВ) і вимірювання параметрів їхнього радіовипромінювання;

- відмінностями законодавчого регулювання використання РЧР в Україні від ряду європейських країн;

- відсутністю необхідного технічного обладнання й відповідного нормативно-методичного забезпечення радіомоніторингу.

Незважаючи на велике різноманіття радіослужб, радіотехнологій, систем i стандартів зв'язку, які нині існують у світі, на практиці для вирішення завдань радіомоніторингу можна використовувати обмежену кількість методів. Це положення радіо технологій на можливості об'єднання радіо технологій, систем зв'язку в групи за певними критеріями, що сприятиме застосуванню єдиних методів виявлення радіовипромінювань, вимірювання їхніх параметрів, пеленгування та визначення місцезнаходження ДРВ тощо. Залишається лише визначити критерії такої класифікації, розподілити системи радіозв'язку на групи за цими критеріями, відмітити для кожної із груп властиві їй методи радіомоніторингу та перелік технічних параметрів, які потрібно вимірювати та (чи) визначати під час його проведення.

На практиці, говорячи про радіомоніторинг, часто мають на увазі дещо інші поняття, зокрема, контроль параметрів радіосигналів у високочастотних трактах.

В основі процедури підбору частот для РЕЗ лежить аналіз ЕМС РЕ3, який полягає в розрахунку ЕMC в районі планування та ЕМС локального угрупування PE3 (об'єктова ЕМС).

Розрахунок ЕМС РЕЗ в районі планування виконується в наступному порядку:

а) вибір по територіальній ознаці РЕ3, розташованих в області обмеженої зони дослідження;

б) вибір із РЕ3, які обрані по територіальній ознаці, по частотній ознаці тих PE3, що потенційно заважають новому частотному присвоєнню:

- визначення можливих джерел завад по основному каналу;

- визначення можливих джерел завад по першому сусідньому каналу;

- визначення можливих джерел завад інтермодуляції 3-го порядку.

в) розрахунок рівня завад на вході приймача:

- по основному каналу;

- по першому сусідньому каналу;

- інтермодуляції 3-го порядку;

г) аналіз отриманих результатів та ухвалення рішення за результатами роз- 
рахунків про можливість частотного присвоєння з урахуванням впливу множинної завади або необхідності вибору іншої частоти.

У випадку позитивного рішення щодо можливості присвоєння частот за результатами розрахунку ЕМС, необхідно перевірити наявність інших РЕЗ на спільному майданчику та, при наявності таких, провести розрахунок ЕМС локального групування РЕ3 (об’єктова ЕМС).

ЕМС локального угрупування РЕЗ виконується в наступному порядку:

а) серед РЕЗ, відібраних відповідно 3 попереднім пунктом вибираються PE3, які розташовані в межах спільного майданчика в колі радіусом до 1 км від БС, що досліджується.

Величина радіусу 1 км обумовлена наступним припущенням - втрати при

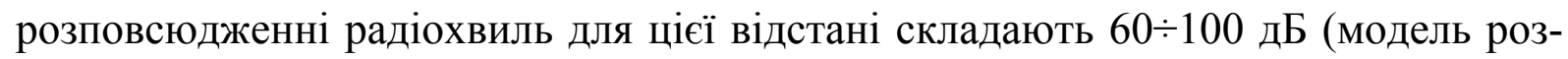
повсюдження у вільному просторі) у залежності від частотного діапазону, що зводить до мінімуму імовірність впливу на приймач інших видів завад на великих відстанях від передавача. Всі станції, що потрапили в зону, обмежену цим колом, вибираються для проведення подальшого аналізу.

б) РЕЗ, які потенційно можуть створювати завади прийому , що досліджується, або підпадають під дію іiі завади, відбираються по частотній ознаці серед РЕЗ, вибраних по територіальній ознаці. Для кожного з відібраних передавачів (чи групи передавачів) перевіряється частотна умова можливості створення завади досліджуваному приймачеві або для кожного 3 відібраних приймачів по групі відібраних передавачів перевіряється частотна умова можливості постановки завад від досліджуваного передавача по наступним видах завад:

- по сусідніх каналах;

- по інтермодуляції 3-го - 13-го порядків;

- по дзеркальному каналу;

- на гармоніках;

- по блокуванню;

в) розраховуються рівні для кожного виду завади;

г) здійснюється аналіз отриманих результатів i, за результатами розрахунків, приймається рішення про можливість частотного присвоєння з урахуванням впливу множинної завади або необхідність вибору іншої частоти. Загальний алгоритм проведення присвоєння частот для РЕЗ приведений на рис. 1.

Втрати при розповсюдженні радіохвиль у вільному просторі [12] (в дБ) визначаються за наступним рівнянням:

$$
L_{\text {Prop }}=32,4+20 \cdot \lg (f)+20 \cdot \lg (r)
$$

де $f$ - частота передавача (МГц); $r$ - відстань між антенами (км). 
Міжвідомчий науково-технічний збірник «Адаптивні системи автоматичного управління» № 2’ (33) 2018

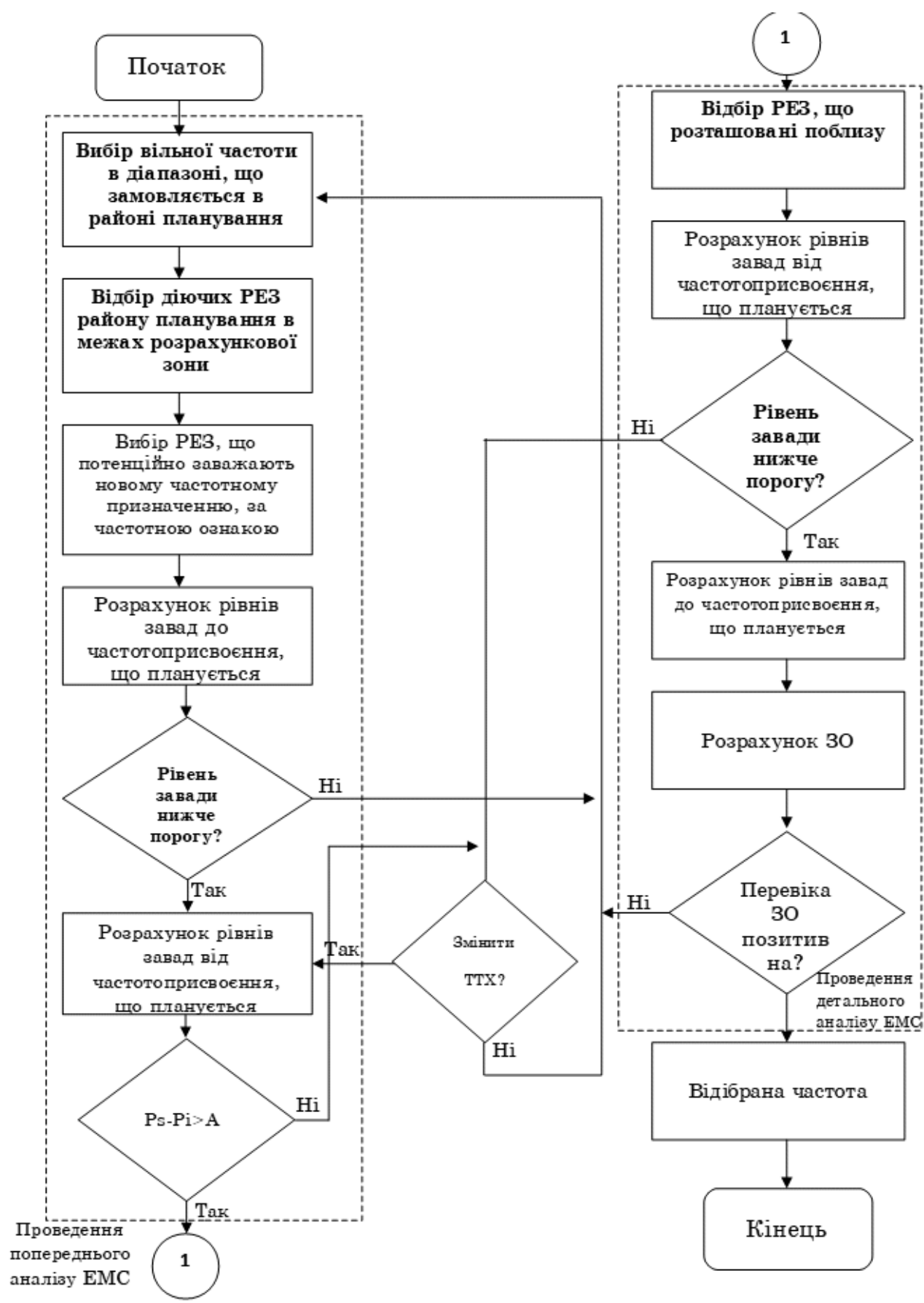

Puc. 1. Загальний алгоритм підбору частот для РЕЗ

На величину втрат розповсюдження радіохвиль у вільному просторі значно впливає як горизонтальний $(\mathrm{R})$, так i вертикальний $(\mathrm{H})$ рознос між антенами. В роботі [13] визначена методика і приведені експериментальні криві, отримані 3 матеріалів досліджень, як функції взаємних втрат розповсюдження радіохвиль між антенами та вертикальним (горизонтальним) розносом між ними. 
Міжвідомчий науково-технічний збірник «Адаптивні системи автоматичного управління» № 2' (33) 2018

Згідно [13] втрати розповсюдження радіохвиль між антенами, рознесеними у вертикальній площині, визначаються як:

$$
L_{V} \approx 28+40 \cdot \lg \left(\frac{H}{\lambda}\right)
$$

де $L_{V}-$ втрати розповсюдження радіохвиль між антенами (дБ); $H$ - відстань по вертикалі між найближчими точками випромінювання антен (м); $\lambda$ - довжина хвилі завади (м).

Втрати розповсюдження радіохвиль між антенами, рознесеними в горизонтальній площині, визначаються [13] як:

$$
L_{H}=22+20 \cdot \lg R-20 \cdot \lg \lambda
$$

де $L_{H}$ - втрати розповсюдження радіохвиль між антенами (дБ); $R$ - відстань по горизонталі між антенами (м); $\lambda$ - довжина хвилі завади (м).

Згідно [13] втрати поширення радіохвиль між антенами, що мають рознос, як у горизонтальної, так і у вертикальній площині визначається:

$$
L_{\text {Prop }}=\frac{\left[28+\left(40 \cdot \lg \cdot\left(\frac{H}{\lambda}\right)\right)\right] \cdot H+\left[22+20 \cdot \lg \cdot\left(\frac{R}{\lambda}\right)\right] \cdot R}{H+R}
$$

На рис. 2 представлені графіки залежності втрат розповсюдження між антенами від відстані (у вертикальній і горизонтальній площинах) між ними, отримані екпериментально [14] і звикористанням формул, приведених вище.

Як видно 3 рис. 2, дані, отримані аналітично, збігаються з результатами експериментальних досліджень.

Як випливає 3 рис. 2, при збільшенні відношення R/ $\lambda$ різниця між величиною втрат, отриманих при розрахунку з урахуванням вертикального розносу між антенами і без його урахування зменшується.

При проведенні розрахунків для різних частотних діапазонів i різних вертикальних розносів між антенами, при відносинах $\frac{R}{\lambda} \geq 200$, похибка не перевищувала 1-2 дБ у діапазоні 30-1000 МГц.

Таким чином, дальню зону можна умовно розділити на дві ділянки:

- $R \leq 200 \times \lambda$, у цьому випадку втрати розповсюдження визначаються по формулі (3.15);

- $R \geq 200 \times \lambda$, у цьому випадку вертикальний рознос між антенами не враховується і розрахунок втрат проводиться за формулою (1). 

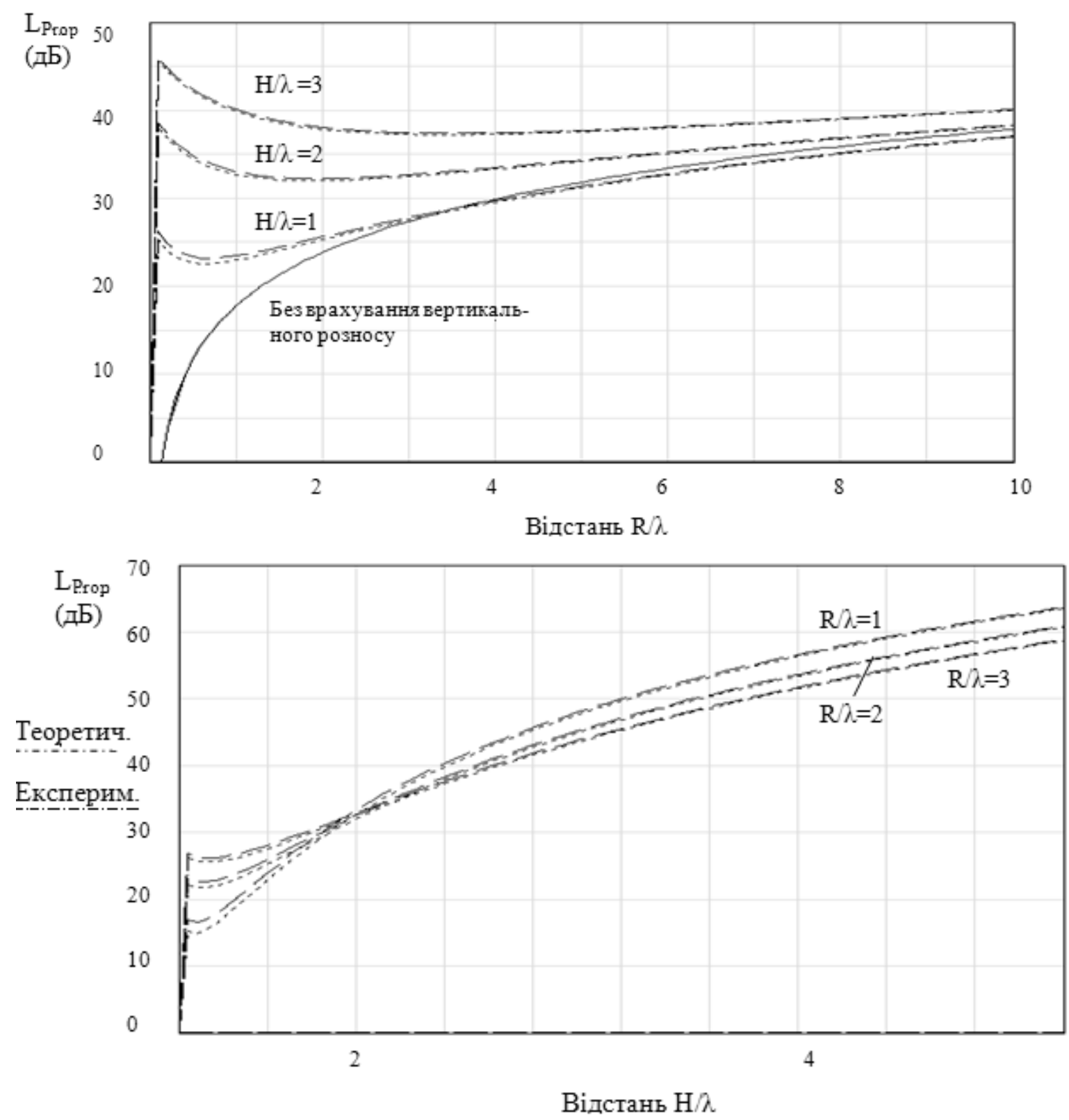

Puc. 2. Втрати розповсюдження при вертикальному та горизонтальному розносі антен

\section{Висновок}

Викладено причини виникнення взаємних завад при роботі радіоелектронних засобів в ускладненій радіоелектронній обстановці, розглянуто сучасний науково-методичний апарат радіомоніторингу з визначенням в ньому електромагнітної обстановки для вирішення задач частотного планування РЕЗ рухомої служби.

Алгоритм припускає проведення аналізу ЕМС РЕЗ у районі планування, а у випадку використання загальної площадки для розміщення РЕЗ - ЕМС локального угруповання РЕЗ (об’єктова ЕМС). 
Міжвідомчий науково-технічний збірник «Адаптивні системи автоматичного управління» № 2' (33) 2018

У алгоритмі враховуються завади наступних видів :

- по основному каналу;

- по першому сусідньому каналу;

- завади інтермодуляції 3-го порядку.

При проведенні аналізу, вищезазначеного алгоритму був встановлений показник ефективності, при менших витратах на виміри електромагнітної обстановки, та рекомендовано для широкого використання цієї методики, при контролю та управління радіочастотним ресурсом і забезпечення електромагнітної сумісності радіоелектронних засобів.

\section{Список використаних джерел}

1. ГОСТ 23611-79 Совместимость радиоэлектронных средств электромагнитная. Термины и определения.

2. Иванов В.А., Электромагнитная совместимость РЭС. К.- Техніка, 1983.

3. Князев А.Д., Элементы теории и практики обеспечения электромагнитной совместимости радиоэлектронных средств. - М.: Радио и связь, 1984.

4. Справочник по управлению использованием спектра на национальном уровне. МСЭ. Бюро радиосвязи. Женева. 1995.

5. Recommendation ITU-R SM. 668-1. Electronic exchange of information for spectrum management purposes.

6. ГОСТ 12252-86, “Радиостанции с угловой модуляцией сухопутной подвижной службы".

7. РНД 45-104-98, “Радіостанції 3 кутовою модуляцією суходільної рухомої служби загального користування."

8. Отчет МСЭ-Р 358-3.

9. WG-SE Report. Evaluation Of Minimum Frequency Separation.

10. Recommendation ITU-R P.341-4. The concept of transmission loss for radio links.

11. Recommendation ITU-R SM.337-4. Frequency and distance separations.

12. Recommendation ITU-R PN.525-2. Calculation of free-space attenuation.

13. Bornemann W. [1981] Aerial Installation on Naval Ship. Summary of the paper presented at Antenna Conference, Karlskrona.

14. Соглашение "Вена-99" (Agreement between the Europe telecommunicationns authorities on the coordination of frequencies between the 29,7-43,5 GHz for fixes services and land mobile services. Vienna, June $\left.30^{\text {th }}, 2000\right)$.

15. Справочник. Сети телевизионного и звукового ОВЧ ЧМ вещания. М.: Радио и связь, 1988. 
16. Reference: TS/SMG-020505Q. European Telecommunications Standards Institute. Digital cellular telecommunications system (Phase 2+); Radio transmission and reception (GSM 05.05).

17. Сканирующие антенные системы СВЧ, т.1; Пер. с англ./ Под ред. Г.Т. Маркова и А.Ф. Чаплина. - М.: Советское радио, 1966.

18. Уолтер К. Антенны бегущей волны; Пер. с англ./ Под ред. А.Ф. Чаплина. - М.: Энергия, 1970.

19. Federal Communications Commission (FCC). Office of Engineering \& Technology. OET Bulletin 65. Edition 97-01.

20. Ерохин Г.А., Чернышов О.В., Козырев Н.Д., Кочержевский В.Г., Антенно-фидерные устройства и распространение радиоволн. М.: Советское радио, 1996.

21. Ерохин Г.А., Кочержевский В.Г., Петровский А.А. Структура ближнего поля проволочных антенн. М.: - Журнал радиоэлектроники, № 3, 1999.

22. Mawrey R. [1998] Determining Power Density Near Antennas to Meet New FCC RF Safety Regulations, UNISite Inc.

23. Recommendation ITU-R IS.851-1. Sharing between the broadcasting service and the fixed and/or mobile services in the VHF and UHF bands.

24. Быховский М.А., Мермельштейн Д.В. Анализ электромагнитной совместимости приемников с учетом явлений блокирования, интермодуляции и перекрестных искажений.

25. Электромагнитная совместимость радиоэлектронных средств и непреднамеренные помехи. Вып.1. Общие вопросы ЭМС: Межсистемные помехи. Пер. с англ. М.: Сов. Радио, 1977.

26. Recommendation ITU-R SM.1134. Intermodulation interference calculations in the land-mobile service. 